\title{
CRUSTAL ZONING OF NEOPROTEROZOIC PRE-COLLISIONAL GRANITOIDS IN THE PARAÍBA DO SUL BELT, RIO DE JANEIRO, BRAZIL
}

\author{
RÔMULO MACHADO ${ }^{1}$, MICHEL DEMANGE ${ }^{2}$, IAN MCREATH ${ }^{1}$ AND JACQUES MOUTTE ${ }^{3}$
}

\begin{abstract}
In the Rio de Janeiro State granites with associated charnockites or charnockitic suites are present in the Litorâneo domain in the internal part of the Paraíba do Sul belt, while plutons without charnockitic rocks occur in the Serra dos Orgãos and Paraíba domains in the external part. In both groups the linear and foliated batholiths are structurally concordant with the regional trends. The two associations usually have slightly expanded compositions with orogenic geochemical features, which are comparable with those for Cordilheran I-type batholiths, but are more evolved. Chemical differences found in the less-differentiated rocks of the two associations disappear in the most evolved terms. The lateral compositional zoning of the less-evolved terms across the belt could have been produced either by magma genesis above a NWdipping subduction zone, or by lateral migration of magmatism during tectonic evolution. The plutons were either emplaced at different, deep crustal levels under amphibolite or granulite facies conditions, or evolved in the presence of different fluids. The pre-collisional magmatism occurred between 560 and $634 \mathrm{Ma}$ ago.
\end{abstract}

Keywords: crustal zoning, pre-collisional, neoproterozoic, granites, charnockites

INTRODUCTION The structures of the Neoproterozoic belts of the Brazilian shield were formed between 1.0 and $0.5 \mathrm{Ga}$ during the Brasiliano/Pan-African cycle (Almeida et al. 1973, Brito Neves and Cordani 1991, Trompette 1994). In the Atlantic coast region of southeastern Brazil, east of the São Francisco Craton, the belts developed under transpression (Machado and Endo 1993, Ebert et al. 1993). Two magmatic arcs are distinguished: the Rio Paraíba do Sul arc with an age between 650-600 Ma (Machado and Demange 1998), and the Rio Doce arc, between 590-480 Ma (Figueiredo and Campos Neto 1993, Campos Neto and Figueiredo 1995, Wiedemann 1993). We will discuss here granitoids from both time intervals.
Neoproterozoic granitoids within the Paraíba do Sul belt in Rio de Janeiro have been separated into three main tectonic groups: (i) pre- to syn-collisional, the main subject of this article; (ii) late collisional; and (iii) post-collisional (Fig. 1). The first is the most expressive, and is mainly composed of I-type plutons (see later). S-type granitoids, which contain aluminous minerals and mica-rich enclaves, are restricted to the southern parts of the Paraíba and Juiz de Fora domains. Late- and post-collisional magmatism has been discussed in recent syntheses (Penha and Wiedemann 1984, Junho 1991 and 1993, Wiedemann 1993, Machado and Demange 1994, Heilbron 1995, Machado 1997), while radiometric ages by different methods have been reported by

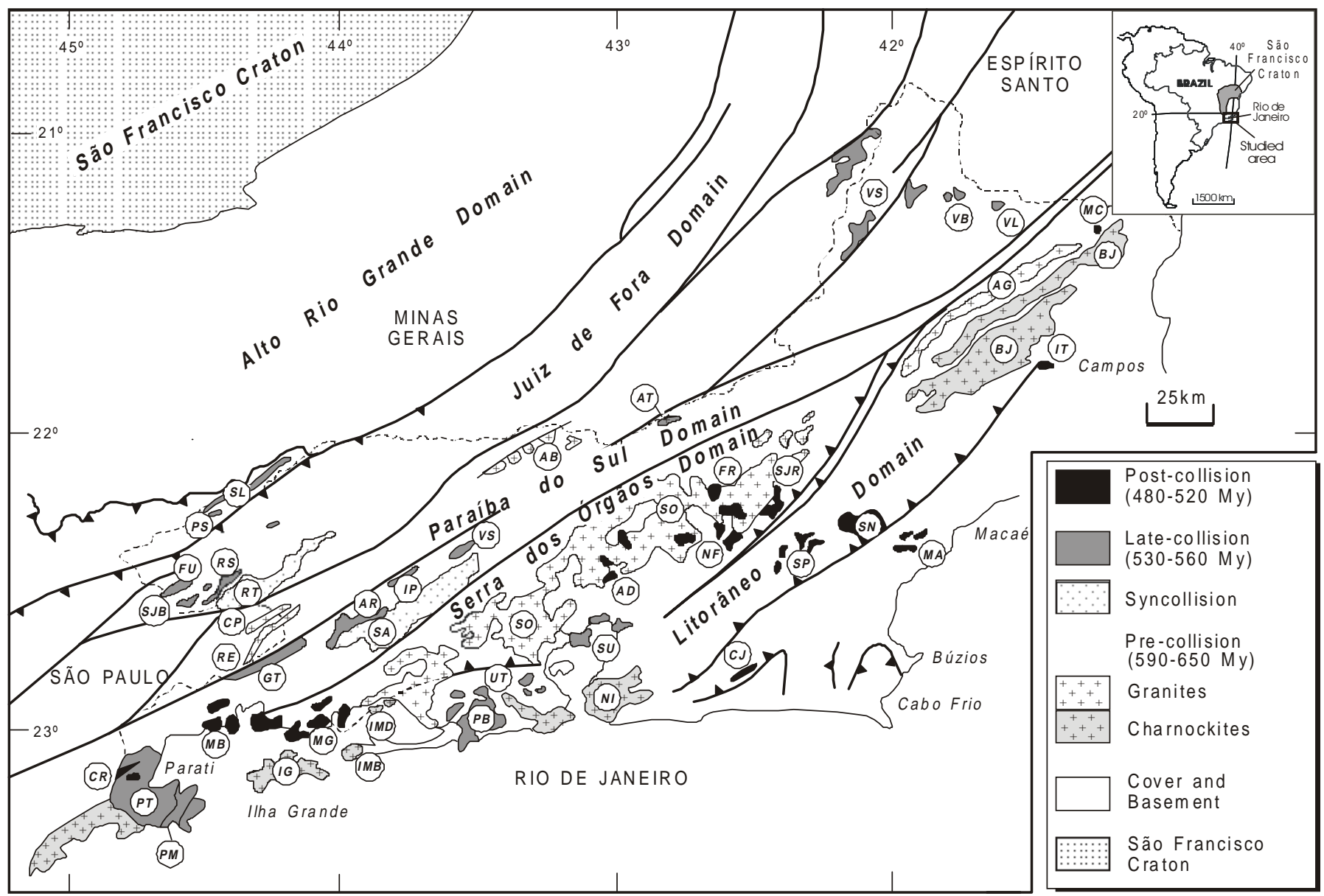

Figure 1 - Geological map of the distribution of Neoproterozoic granites of the Rio de Janeiro State (Modified from Machado and Demange 1994 and 1998). Pre-collision Granites: AB - Serra das Abóboras; CP - Campinho; SO - Serra dos Órgãos; RE - Resgate; AG - Angelim; BJ - Bela Joana; NI - Niterói; IMB - Ilha da Marambaia; IMD - Ilha da Madeira; IG - Ilha Grande. Syncollision Granites: SA - Serra das Araras and RT - Rio Turvo.

1 - Universidade de São Paulo, Instituto de Geociências, Caixa Postal 11348, 05422-970, São Paulo-SP, Brazil.

2 - Ecole des Mines, 35 rue Saint-Honoré, 77305 Fontainebleau, FRANCE

3 - Ecole des Mines de Saint-Etienne, Cours Fauriel, 42023 Saint-Etienne, France 
Delhal et al. (1969), Cordani et al. (1973), Valladares (1996), Machado N. et al. (1996), Machado R. et al. (1996) and Tupinambá (1999). Elongated late-collisional plutons with ages around $530-535 \mathrm{Ma}$ mainly occur along high angle ductile shear zones within the Paraíba domain, while 491-501Ma post-collisional granites mostly occur in the hills around Petrópolis, and near Paratí, close to the Rio de Janeiro São Paulo state boundary.

THE CENTRAL SEGMENT OF THE PARAíbA DO SUL BELT The Paraíba do Sul belt in the Rio de Janeiro State is formed by four domains, separated by ductile shear zones with predominantly horizontal slip. From SE to NW the domains are: Litorâneo (North and South), Serra dos Órgãos, Paraíba (North and South) and Juiz de Fora (Fig. 1). The shear zones are high angle, except for the contact between the Juiz de Fora and Paraíba Norte domains, which is medium/low angle. The main metamorphic and structural features of the first three domains were imposed during the Neoproterozoic, while the Juiz de Fora domain is dominantly Paleoproterozoic. Metamorphic grade is mainly amphibolite in the first three domains, while in the Juiz de Fora domain granulite facies rocks predominate. In all domains, migmatized orthogneisses of the Paleoproterozoic basement and Proterozoic metasediments are present.

The Paraíba domain is divided into northern and southern segments by the high-angle, dextral Além Paraíba do Sul ductile shear zone, one of the most important Precambrian structures in this part of the belt in Rio de Janeiro, and part of Paraíba do Sul regional shear system in the Atlantic shear belt (Machado and Endo 1993). This ductile shear forms the axial zone of a positive flower structure developed during the Neoproterozoic. The importance of this shear zone in determining the tectono-structural evolution of the region is well-known, but few authors have recognized its importance in the control of magmatism at this time (Machado and Endo 1993). Late collisional, syn-F3 granites occur exclusively within this shear zone (Machado and Demange 1988), while pre-collisional I-type granite occur mainly south of this structure.

\section{THE PRE-COLLISIONAL GRANITES IN THE STUDIED}

AREA The Neoproterozoic granitoids are classified as precollisional, because some of them present major and trace element geochemical features which have been associated with this tectonic type. By extension, massifs, which have similar petrographical, structural and textural features, are included in this group.

Table 1 presents a summary of available geochronological data for the pre- collisional granites in the studied area, showing that their intrusion occurred between 634 and $560 \mathrm{Ma}$. The granites mainly occur south of the Além-Paraíba ductile shear zone, in the Serra dos Órgãos and Litorâneo domains (Fig. 1). Their lineated and foliated batholiths are structurally concordant with the regional NE-SW and NNE-SSW trends of belt. The rock suites are usually slightly expanded

Table 1 - Radiometric data of Neoproterozoic pre-collisional granites in the studied region.

\begin{tabular}{|llcl|}
\hline \multicolumn{1}{|c}{ Batholith } & \multicolumn{1}{c}{ Age (reference) } & Method & \multicolumn{1}{c|}{ Material } \\
Angelim & $502(1), 612(2)(3)$ & $\mathrm{Rb}-\mathrm{Sr}$ & Whole rock \\
Bela Joana & $599(4)$ & $\mathrm{Rb}-\mathrm{Sr}$ & Whole rock \\
Niterói & $531,537,564,611(2)$ & $\mathrm{Rb}-\mathrm{Sr}$ & Whole rock \\
& $(3)$ & & \\
Rio Negro & $474,956(5)$ & $\mathrm{Rb}-\mathrm{Sr}$ & Whole rock \\
& $580(5)$ & $\mathrm{Pb}-\mathrm{Pb}$ & Zircon \\
& $634(5)$ & $\mathrm{U} / \mathrm{Pb}$ & Zircon \\
Serra dos Órgãos & $567(6), 570(7)$ & $\mathrm{Rb}-\mathrm{Sr}$ & Whole rock \\
& $624(2), 599(3)$ & $\mathrm{Rb}-\mathrm{Sr}$ & Whole rock \\
& $620(6)(8)$ & $\mathrm{U} / \mathrm{Pb}(\mathrm{li} *)$ & Zircon, titanite \\
& $560(5)$ & $\mathrm{U} / \mathrm{Pb}(\mathrm{hi} *)$ & Zircon \\
Serra dos Órgãos & $589-599$ & $\mathrm{~Pb}-\mathrm{Pb}$ & Zircon \\
leucogranites & & & \\
\hline
\end{tabular}

(*) lower intercept (li); higher intercept (hi); Reference: (1) Batista and Kawashita (1985); (2) Machado R. et al. (1996); (3) Machado R.(1997); (4) Batista (1984); (5) Tupinambá (1999); (6) Valladares (1996); (7) Machado N. et al. (1996); (8) Delhal et al. (1969); (9) Porto et al. (1996); (10) Cordani et al. (1973). (e.g. tonalite/granodiorite/granite or enderbite/charno-enderbite/ charnockite), comparable to those of the Cordilleran I-type batholiths, but with more evolved petrographic and geochemical features. The spatial distribution of the suites is zoned, with charnockites or the charnockitic association rocks possibly occupying deeper intrusion levels in the internal part of the belt, and granitoids without charnockites forming shallower intrusions in the external part.

In the Litorâneo domain, the massifs are mainly composed of charnockites or rocks of the charnockitic suite. The Angelim tonalitic gneiss massif of the northeastern limit of this domain is the only exception. In the Rio de Janeiro State the charnockitic massifs form a $>400 \mathrm{~km}$ belt, which continues southwestwards into the São Paulo State near Ubatuba, and northeastwards into Espírito Santo. Rb-Sr whole-rock isochron ages around $600 \mathrm{Ma}$ have been obtained for charnockites in the Rio de Janeiro region (Batista 1984).

The Serra dos Órgãos domain contains the homonymous $165 \times 30$ $\mathrm{km}$ batholith, one of the largest in the region. The granitoids contain biotite and amphibole, and the common accessories are zircon, apatite, opaque minerals, allanite and titanite. The rocks are medium- to coarse-grained, inequigranular, and sometimes porphyritic. Textures are usually foliated, granoblastic and recrystallized. Mylonitic rocks are common especially near the borders of the massifs. Chemical data indicate medium- to high-K, metaluminous to slightly peraluminous, and calcic to alkali-calcic compositions.

Rocks of the charnockitic association are usually more calcic and richer in $\mathrm{Mg}$ and $\mathrm{Ti}$, and poorer in $\mathrm{K}, \mathrm{Fe}, \mathrm{Mn}, \mathrm{Ba}$, Th, and HFSE than the rocks of the granitic association (Fig. 2), but these differences disappear in the more evolved terms (see, for example, the $\mathrm{CaO}$ vs. $\mathrm{K}_{2} \mathrm{O}$ diagram). The compositions of some of the intermediate Serra dos Órgãos rocks are sufficiently iron-rich for their compositions to fall in the tholeiitic field of the AFM diagram. Tectonic discrimination diagrams with major elements identify the rocks as pre-collisional or mantle fractionates, while the trace elements point to syn-collisional or volcanic arc (also pre-collisional) origin (Fig.2).

Geothermometric and geobarometric determinations using garnetbiotite and garnet-plagioclase pairs indicate P-T conditions of about $738^{\circ} \mathrm{C}$ and $5.8 \mathrm{Kbar}$ for the Bela Joana charnockite massif, between 787-869 ${ }^{\circ} \mathrm{C}$ and between 5.2-6.6 Kbar for the Angelim tonalite, (Rêgo 1989), conditions which are generally compatible with emplacement under amphibolite to granulite facies conditions, but probably reflect post magmatic recrystallization.

DISCUSSION AND CONCLUSIONS Although the intrusion intervals for the two main granitic associations overlap, two age groups may be separated (Table 1). One group between 634 and $590 \mathrm{Ma}$ includes the charnockite belt in the southern part of the Litorâneo domain, and the pre -collisional granites of the Rio Paraíba do Sul magmatic arc, while the other between 580 and 560 Ma corresponds to the pre-collisional intrusions of the Rio Doce magmatic arc.

The lateral distribution of pre-collisional granite types across the belt is comparable to that of recent orogens such as the MesozoicCenozoic Cordilleras of the Western North and South America. Additionally, this belt may have a zonation of the depth of emplacement, with deeper batholiths (i.e. charnockites or the charnockite association in the Litorâneo domain) intruded under high amphibolite or granulite facies conditions in the internal part of belt and shallower intrusions under amphibolite facies (i.e. granites without charnockite association in the Serra dos Órgãos and Paraíba do Sul domains) in the external part of the belt towards the craton. Nevertheless, the hypothesis of lateral migration of magmatism in the transpressive regime also has been discussed to explain this magmatic zoning in the orogenic space, and different fluids may have been associated with the two different rock associations.

Acknowledgements To the Laboratory of Geochemistry of the École des Mines de Saint-Etienne for the chemical analysis, to FAPESP (Processes 90/1907-6; 92/4379-6) for support of the fieldwork, and to the programme CAPES/COFECUB (Project 158/ 94). RM and IMcR acknowledge CNPq research fellowships. To two anonymous referees of RBG for the critical review of the manuscript. 

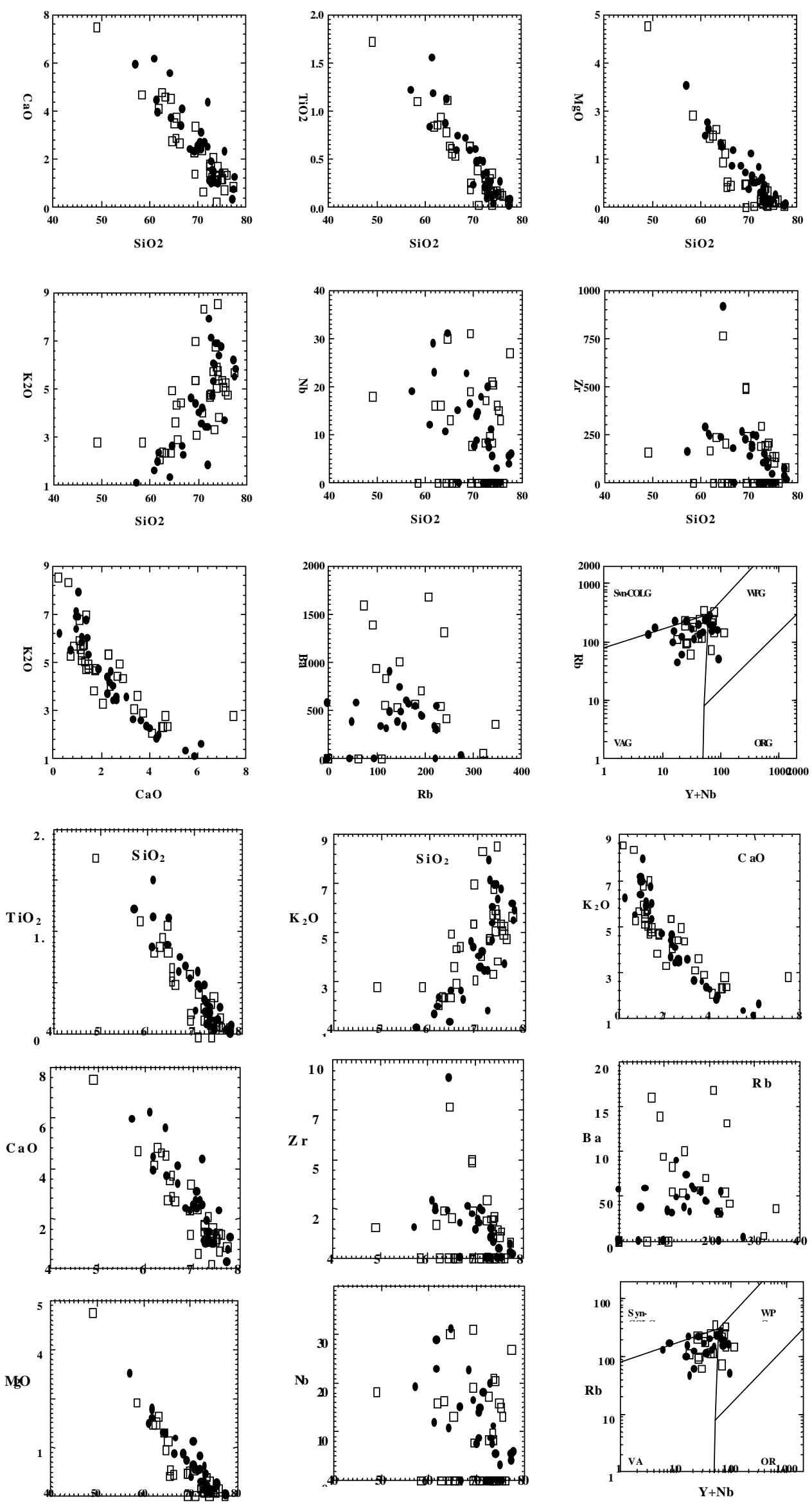

Figure 2 - Harker variation and tectonic discrimination diagrams for the studied granitoids. Symbols: circles = granites with associated charnockites; squares = granites without charnockites. 


\section{References}

Almeida F.F.M., Amaral G., Cordani U.G., Kawashita K. 1973. The Precambrian evolution of the South America cratonic margins. In: Ocean Basins and Margins (Edited by of the South America cratonic margins. In: Ocean Basins and Margins (Edited by

Batista J.J. 1984. Caracterização dos processos evolutivos precambrianos na região de São Fidélis, norte do Estado do Rio de Janeiro. Inst. Geociências, Universidade de São Paulo, São Paulo, Tese de Doutoramento, 123 p.

Batista J.J. \& Kawashita K. 1985. Contribuição ao acervo geocronológico da porção setentrional do cinturão Ribeira .In: Simpósio Regiona de Geologia, 5., São Paulo, Atas 1:187-200

Brito Neves B.B. \& Cordani U.G. 1991. Tectonic evolution of South America during late Proterozoic. Precambrian Research, 53:23-40.

Campos Neto M.C. \& Figueiredo M.C.H. 1995. The Rio Doce orogeny, Southeastern Brazil. J. South Amer. Earth Sci., 8:143-162.

Cordani U.G., Delhal J., Ledent D.1973. Orogénèses superposées dans le Pré-Cambrian du Brésil Sud-Oriental (États de Riode Janeiro et de Minas Gerais). Revista Brasileira de Geociências, 3:1-22.

Delhal J., Ledent D., Cordani U.G. 1969. Ages U/Pb, Rb/Sr et K/Ar de formations métamorphiques et granitiques du Sud-Est du Brésil (Ëtats de Rio de Janeiro et de métamorphiques et granitiques du Sud-Est du Brésil
Minas Gerais ). Ann. Soc. Géol. Belg. 92:271-283.

Ebert H.D., Hasui Y., Sartoro G., Almeida S.H., Costa J.B.S. 1993. Arcabouço estrutural tectônica transpressiva das faixas móveis da borda sul e sudeste do cráton do São Francisco e da síntaxe de Guaxupé. In: Simpósio Nacional de Estudos Tectônicos, 4 . Belo Horizonte, Resumos Expandidos, p. 166-171.

Figueiredo, M.C.H.; Campos Neto, M.C. 1993. Geochemistry of the Rio Doce magmatic arc, Southeastern Brazil. An. Acad. Bras. Ciênc., 65 (Supl. 1): 63-81.

Heilbron M. 1995. O segmento central da Faixa Ribeira: síntese geológica ensaio de evolução geotectônica. Depto. de Geologia/Geofísica, Universidade Estadual do Rio de Janeiro, Rio de Janeiro, Livre-Docência Thesis, 110 p.

Junho M.C.B. 1991. Contribuição à petrografia dos macicos graníticos da Pedra Branca, Frades e Nova Friburgo, Rio de Janeiro.Inst. Geociências, Universidade do Rio de Janeiro, Rio de Janeiro, Tese de Doutorado, 198 p.

Machado R. 1997 . Litogeoquímica e tectônica dos granitóides Neoproterozóicos do cinturão Paraíba do Sul no Estado do Rio de Janeiro. Inst. Geociências, Universicinturão Paraíba do Sul no Estado do Rio de Janeiro. Inst. Geociências,

Machado R. \& Demange M. 1994. Classificação estrutural e tectônica dos granitóides Neoproterozóicos do Cinturão Paraíba do Sul no Estado do Rio de Janeiro. Boletim do IG-USP, Série Cient., 25:81-96.
Machado, R.; Demange, M. 1998. Caracterização geoquímica e tectônica dos granitóides pré-colisionais neoproterozóicos do cinturão Paraíba do Sul no Estado do Rio de Janeiro. In: Conceição H., Cruz M.J., Sá J.H.S., Sabaté P. (eds.), Contribuição ao estudo dos granitos e rochas correlatas. Publicação Especial 5, SBG, Núcleo BASE, p. 21-39.

Machado R., Demange M., Viallete Y. 1996. Idades geocronológicas Rb/Sr da granitogênese brasiliana no segmento setentrional da faixa Ribeira, Estado do Rio de Janeiro. In: SBG, Congresso Brasileiro de Geologia, 39, Salvador, Resumos Expandidos, 1:38-40.

Machado R. \& Endo I. 1993. O Cinturão de Cisalhamento Atlântico: um exemplo de tectônica transpressional neoproterozóica. In: Simpósio Nacional de Estudos Tectônicos, 4, Belo Horizonte, Resumos Expandidos, p. 188-191.

Pearce J.A., Harris N.B.W., Tinldle A.G. 1984. Trace element discrimination diagrams for the tectonic interpretation of granitic rocks. J. Petrol., 25:956-983.

Penha H.M. \& Wiedemann C.M. 1984. Granitóides da região central do Estado do Rio de Janeiro. In: SBG, Congresso Brasileiro de Geologia, 33, Rio de Janeiro, Roteiro de Excursões, p. 5433-5456.

Porto Jr. R., Sanchez B., Meighan I.G., Fallick A.E. 1996. RJ. Geologia, geoquímica geocronologia do batólito Serra dos Órgãos. In: SBG, Congresso Brasileiro de Geologia, 38., Salvador, Anais 6:445-448.

Rêgo I.T.S.F. 1989. Petrologia e geoquímica da unidade charnockítica Bela Joana, região de São Fidélis, RJ. Inst. Geociências, Universidade de São Paulo, São Paulo, Tese de Doutoramento, $348 \mathrm{p}$.

Trompette R. 1994. Geology of the Western Gondwana (2000 - 500 Ma): Pan-AfricanBrasiliano aggregation of South America and Africa. Rotterdam, 350p

Tupinambá M. 1999. Evolução tectônica e magmática da Faixa Ribeira na região serrana do Estado do Rio de Janeiro. Inst. Geociências, Universidade de São Paulo, São Paulo, Tese de Doutoramento, $221 \mathrm{p}$.

Valladares C. 1996. Evolução geológica do complexo Paraíba do Sul, no segmento central da Faixa Ribeira, com base em estudos de geoquímica e geocronologia $U$-Pb. Inst. Geociências, Universidade de São Paulo, São Paulo, Tese de Doutoramento, $147 \mathrm{p}$

Wiedemann C.M. 1993. The evolution of the Paleozoic, late- to post-collisional magmatic arc of the coastal mobile belt, in the state of Espiríto Santo, eastern Brazil. Anais da Academia Brasileira de Ciências, 65 (Supl. 1):163-181.

Contribution IGC-099

Received March 1, 2000 Accepted for publication May 3, 2000 